\title{
Role of human microbiome and selected bacterial infections in the pathogenesis of rheumatoid arthritis
}

\author{
Ewa Roszyk, Mariusz Puszczewicz \\ Chair and Clinic of Rheumatology and Internal Diseases, Poznan University of Medical Sciences, Poznan
}

\begin{abstract}
Microorganisms inhabiting human body form a complex ecosystem. The mutual influence of the microbiome and the immune system of the host constitute the basis for numerous diseases, e.g. pseudomembranous colitis, inflammatory bowel disease, type 1 diabetes, atopic diseases, obesity, reactive arthritis. New molecular diagnostic methods and multi-center studies may help in understanding of the role of microbiota in health and disease. Rheumatoid arthritis has a multi-faceted etiology, and its causes are not entirely understood. There are indications for the influence of microbiomes of oral cavity, intestines, lungs and urinary tract on the development of rheumatoid arthritis. Interactions between microorganisms and human immune system play role in the pathogenesis of the disease.
\end{abstract}

Key words: microbiome, periodontal disease, rheumatoid arthritis.

\section{Introduction}

Rheumatoid arthritis is a chronic inflammatory disease with still unknown causes. The recognized etiological factors are: e.g., HLA-DR genes, tyrosine phosphatase gene (PTPN22), gene of peptidylarginine deiminase $(P A D /)$, cytokine coding genes. However, it is believed that genetic factors determine development of the disease in less than 50\%. The best known environmental factor is smoking tobacco. Furthermore, the risk of seronegative rheumatoid arthritis increases in persons with excessive body weight. The role of bacterial or viral antigens has been suggested in the pathogenesis of the disease [1].

Body of an adult human consists of approx. $10^{13}$ cells, yet it bears the load of as much as $10^{14}$ microbial cells: primarily prokaryotic organisms (over 1000 species of bacteria and archeons), as well as fungi, viruses and protozoans. This set of microorganisms, referred to as microbiome, colonizes the surface of the skin (approx. $1.73 \mathrm{~m}^{2}$ ) and mucous membranes (approx. $300 \mathrm{~m}^{2}$ ), entering into constant interactions with the host. Typically, this consti- tutes a harmonious coexistence, bringing mutual benefits [2]. It is assessed that the human digestive system is inhabited by 1-2 kg of bacteria (approx. 1150 species), mostly obligate anaerobes [3, 4]. Skin contains approximately $10^{12}$ bacteria, primarily Gram-positive aerobic, as well as facultative anaerobes (e.g., Staphylococcus, Corynebacterium). The remaining sites naturally inhabited by bacteria are the vagina and external portion of the urethra in women [2] upper respiratory as well as lower respiratory tracts, until recently believed to be sterile [5].

Colonization occurs directly after birth and continues throughout the entire life. The mechanisms of non-specific and specific immunity of the host prevent excessive growth of microorganisms and their penetration inside the tissues. Moreover, the immune system is responsible for the formation of tolerance to their antigens and it ensures both survival of the necessary microorganisms as well as protection of the human organism against the results of unnecessary inflammatory reaction. These compounds are of such importance that disorders in the microbiome (dysbiosis) does not only result in causing numerous diseases, such as pseudomembranous colitis, 
Table I. Human microbiome investigation projects

\begin{tabular}{|c|c|c|c|}
\hline Project & Population & Body site & References \\
\hline $\begin{array}{l}\text { MetaHIT } \\
\text { (Metagenomics of the } \\
\text { Human Intestinal Tract) }\end{array}$ & $\begin{array}{l}124 \text { Europeans from } 8 \text { UE states (heathy } \\
\text { subjects, patient with obesity, patients } \\
\text { with inflammatory bowel disease) }\end{array}$ & Stool probes & $\begin{array}{c}\text { http://www.metahit.eu } \\
\text { http://www.sanger.ac.uk/resources/ } \\
\text { downloads/bacteria/metahit/ [4] }\end{array}$ \\
\hline $\begin{array}{l}\text { Human Microbiome } \\
\text { Project }\end{array}$ & $\begin{array}{l}242 \text { healthy adults, } \\
\text { USA }\end{array}$ & $\begin{array}{l}18 \text { body } \\
\text { sites probes }\end{array}$ & [46] \\
\hline $\begin{array}{l}\text { The Global Gut } \\
\text { Microbiome }\end{array}$ & $\begin{array}{l}531 \text { healthy children and adults, } \\
\text { Venezuela, Malawi, USA }\end{array}$ & Stool probes & [47] \\
\hline $\begin{array}{l}\text { American Gut } \\
\text { Project }\end{array}$ & $\begin{array}{c}3832 \text { children and adults (recruitment } \\
\text { ongoing), USA }\end{array}$ & $\begin{array}{l}\text { stool, skin, } \\
\text { oral cavity }\end{array}$ & $\begin{array}{l}\text { https://www.microbio.me/AmericanGut/ } \\
\text { static/img/mod1_main.pdf [49] }\end{array}$ \\
\hline
\end{tabular}

intensified susceptibility to Salmonella and Citrobacter infections or mycosis, but they also appear to be among the significant etiological factors of such diseases as: inflammatory bowel disease (IBD), type 1 diabetes, atopic diseases, obesity [6]. The influence of bacteria or bacterial antigens on the development of arthritis has already been demonstrated for spondyloarthritis - the typical example here is reactive arthritis, enteropathic arthritis and the contribution of similar mechanisms has been confirmed for psoriatic arthritis. The term "joint-gut axis" has been even used for these ailments. The contribution of microbiome in rheumatoid arthritis has also been taken into consideration.

The modern techniques for microorganism detection help in the study of microbiome and its relation to specific diseases. A classic microbial culture detects only approx. $20 \%$ of microorganisms, particularly in terms of the intestine flora, consisting primarily of obligate anaerobes. The majority of these organisms can be detected and classified using molecular probes for $16 \mathrm{~S}$ ribosomal RNA, analysis of DNA or proteins (phylotypes rather than species are detected in this manner) [7].

In order to determine the role of bacteria large research projects have been established (Table I).

\section{Intestine microbiome}

As far as the gastrointestinal tract is concerned, bacteria inhabit primarily the large intestine and ileum, and considerably lower numbers are found in the jejunum, and only singular species are found in the stomach or duodenum (Helicobacter pylori). The vast majority (ap-

Table II. Bacteria dominating in healthy gut $[2,3,7,8,48,49]$

\begin{tabular}{|c|c|c|c|}
\hline Type & Class & Genus & Role and metabolism \\
\hline Bacteroidetes & Bacteroidetes & $\begin{array}{c}\text { Bacteroides } \\
\text { Prevotella }\end{array}$ & $\begin{array}{l}\text { Polysaccharide decomposition, nu- } \\
\text { trients absorption, maturation and } \\
\text { maintenance of endothelial cells }\end{array}$ \\
\hline \multirow[t]{2}{*}{ Firmicutes } & Clostridia (95\%) & $\begin{array}{c}\text { Clostridium cluster IV i Clostridium XIVa } \\
\text { Eubacterium } \\
\text { Ruminococcus } \\
\text { Dorea } \\
\text { Blautia }\end{array}$ & $\begin{array}{l}\text { Production of short-chain fatty } \\
\text { acids, ex. acetic, propionic, butyric } \\
\text { acid, which contitute the source of } \\
\text { energy for human cells (Clostridium) }\end{array}$ \\
\hline & Bacilli & $\begin{array}{l}\text { Lactobacillus } \\
\text { Bacillus subtilis } \\
\text { Streptococcus }\end{array}$ & \\
\hline Actinobacteria & Actinobacteria & $\begin{array}{l}\text { Bifidobacterium } \\
\text { Collinsella }\end{array}$ & Fermentation of oligosaccharides \\
\hline Proteobacteria & & $\begin{array}{c}\text { Escherichia } \\
\text { Enterobacter } \\
\text { Other Enterobacteriaceae }\end{array}$ & Decomposition of mucins \\
\hline \multicolumn{4}{|l|}{ Fusobacteria } \\
\hline Verrucomicrobia & Verrucomicrobiae & Akkermansia & \\
\hline $\begin{array}{l}\text { Other and unclassified } \\
\text { new phylotypes } \\
\text { (Cyanobacteria included) }\end{array}$ & & & \\
\hline
\end{tabular}


prox. 90\%) of intestinal bacteria consists of obligate anaerobes (Table II).

Based on the study of intestinal microbiome it has been demonstrated that it is characterized by considerable variation between individuals, as well as within individuals. In time, however, the variation is not continuous. Three enterotypes can be distinguished in the human population [8]: enterotype 1 - characterized by the prevalence of Bacteroides, Parabacteroides and Clostridiales, entrotype 2 - Prevotella and Streptococcus; enterotype 3 - Ruminococcus, Akkermansia, Methanobrevibacter. This division is valid for the American and European population, yet in the Danish group enterotype 3 is dominated bygenera Clostridiales, Blautia and non-classified Lachnospiraceae (which may correspond to Ruminococcus, depending on the testing methods). Enterotypes do not depend on sex or geographic area, thus far no factors causing given person to posses the specific enterotype. However, separate clusters of genes characterizing patients with ulcerative colitis and Leśniowski-Crohn's disease have been demonstrated.

The role of intestinal bacteria in degradation of complex carbohydrates, production of short-chain fatty acids, essential amino acids, $\mathrm{B}$ and $\mathrm{K}$ vitamins, degradation of numerous xenobiotics, for instance benzoate, is widely acknowledged [4]. Microorganism participate in the stimulation of angiogenesis in the intestine, and even in regulation of adipose tissue metabolism in the organism [7]. Moreover, they protect against colonization by pathogenic microorganisms. However, of special interest for rheumatologists must be the influence of microbiome on the maturation of the host's immune system.

The influence of the presence of bacteria on the development of gut associated lymphoid tissue (GALT) has been proved. Mice bred in germ-free conditions possess hypoplastic Peyer's patches, which contain few propagation centers, low number of plasmocytes and CD4+ cells in the lamina propria. However, these disorders are not restricted to the mucosa: the spleen and axillary lymph nodes of such animals are characterized by poor structure, with weakly formed zones [9]. Moreover, the balance between lymphocyte Th1 and Th2 is disturbed in comparison to individuals bred in normal conditions. The colonization of Bacteroides fragilis of a previously sterile gastrointestinal tract of mice restores the balance between Th1/Th2. This is caused by, among others, presentation of the bacterial polysaccharide by the dendritic cells [10].

Moreover, the immune system comes into contact with the heat shock proteins (HSPs) of the bacteria. The HSPs possess similar structure in prokaryotic as well as eukaryotic organisms, including humans. The role of response against these proteins in the pathogenesis of rheumatoid arthritis is complex and still being studied. However, it is known that the immunization with HSP 60, HSP 70, HSP 40 proteins stimulates mononuclear cells to secrete anti-inflammatory interleukin 10 (IL-10), and in the culture of synoviocytes it leads to the reduction of production of pro-inflammatory IL-6 and IL-8 [11].

In rheumatoid arthritis, similarly to certain other autoimmune diseases, blood and synovial membrane of patients contain higher number of Th-17 lymphocytes (subclass of auxiliary lymphocytes) and lower number of Treg lymphocytes than in healthy humans. Th-17 lymphocytes stimulate macrophages to produce tumor necrocis factor (TNF), IL-1 and IL-6 [1]. The microbiome is capable of action here as well. Butyric acid produced by intestinal bacteria can induce the differentiation of Treg lymphocytes [12]. Similarly, polysaccharide A produced by Bacteroides fragilis can promote maturation of CD4+ lymphocytes into Treg lymphocytes and stimulates them to produce IL-10. This occurs via Toll-like receptor (TLR-2), found on lymphocytes and dendritic cells, which binds bacterial peptidoglycan. Furthermore, polysaccharide A causes reduced expression of TNF in monocytes stimulated by lipopolysaccharide [13-15].

An example of reversed, "proinflammatory" action of intestinal commensals is induction of the presence and activation of Th17 lymphocytes and stimulation of their secretion of IL-17 by segmented filamentous bacterium (SBF) in mice. Animals colonized by this species of bacteria were more immune to infection with pathogenic strains [16]. On the other hand, Clostridium colonization contributes to the accumulation of Treg lymphocytes in the mucosa and increase of TGF $\beta$ concentration, helping mice to be resistant to enteritis [17].

Animal models also demonstrated relationship between arthritis and intestine microbiome. Rodents, in which arthritis was triggered exhibited stronger inflammation symptoms, when they were bred in germ-free conditions [18]. The presence of bacteria appeared to act primarily through stimulation of Th17 cells in intestine and the entire organism, as well as through reduced production of Treg cells and intensified permeability of the bowels [19]. However, certain studies brought opposite conclusions. Researchers of the Uppsala University (Sweden) demonstrated (for animal arthritis models) lack of relationship between the severity of arthritis and the presence of bacteria in the gastrointestinal tract and production of p/HSP-65 antibodies [20].

Vaahtovuo et al. [3] demonstrated for the group of 101 patients that persons with early rheumatoid arthritis (not yet subjected to treatment with disease modifying anti-rheumatic drugs - DMARDs - or steroids) possessed a different intestine microflora composition than the control group (patients with fibromyalgia). Presence 
of bacteria in stool was tested using RNA probes. In patients with rheumatoid arthritis, lower numbers of Bifidobacteria and Bacteroides-Porphyromonas-Prevotella (6.9\% vs. 9.8\%) group, Bacteroides fragilis subgroup and Eubacterium rectal - Clostridium coccoides group were found [3]. Patients with fibromyalgia were selected as the control group due to similar exposure to non-steroidal anti-inflammatory drugs (NSAIDs) and lack of inflammation symptoms. However, missing in the study was comparison with healthy patients.

Chinese researchers evaluated the Lactobacillus species composition in stool samples from patients with early rheumatoid arthritis. Each of the groups: examined and control (healthy volunteers) included 15 persons. It turned out that larger counts of $L$. salivarius, $L$. iners and $L$. ruminis were found in patients than in the control group and L. mucosae was found solely in patients with rheumatoid arthritis [21].

A recent Chinese study compared the total number of 212 stool samples: A total of 94 non-treated patients with rheumatoid arthritis and from 80 healthy unrelated and 17 healthy related persons as well as 21 patients with rheumatoid arthritis treated with DMARDs [22]. The flora composition did not only differ the group of patients with rheumatoid arthritis from healthy persons, but it also correlated with the activity of the disease, as well as partially with immunoglobulin concentrations. Higher counts of Gram-positive bacteria and lower counts of Gram-negative bacteria (including lower counts of Proteobacteria and Firmicutes of the Veillonellaceae) were found in patients with rheumatoid arthritis. Higher count of Lactobacillus salivarius was found and lower occurrence of the genus Haemophilus, Klebsiella pneumoniae, Bifidobacterium bifidum, Sutterella wadsworthensis, Megamonas hypermegale. Organisms of the patients contained higher counts of Bacteroides, yet Bacteroides plebeius was more common in the control group. After the modifying treatment (primarily methotrexate, Tripterygium wilfordii glycosides used in traditional Chinese medicine, less frequently leflunomide, prednisolone, hydroxychloroquine and etanercept), composition of the flora was similar to healthy patients. According to authors the result of their study supports the hypothesis that chronic inflammation in rheumatoid arthritis may be caused or intensified by the growth of pathogenic bacteria or deficiency of immunomodulatory commensal bacteria. However, a question can be raised, whether, as therapy partially restores the "healthy" microbiome, the disturbance of its composition is rather a coincidence or even a result of immune processes leading to rheumatoid arthritis.

Scher et al. [23] studied microbiome of patients with newly diagnosed RA, chronic treated RA and psoriatic ar- thritis (PsA) (total number of 114 patients). Prevotella copri was significantly more common in the intestine flora in the group of newly diagnosed RA (NORA - new-onset untreated rheumatoid arthritis). Prevotella copri colonization increased the risk of RA from $1 \%$ to $3.95 \%$. Moreover, patients with NORA were found to possess such bacteria genera as: Catenibacterium, Veillonella, less frequently Clostridia, Lachnospiraceae, and Bacteroides (this relationship was not found in patients with chronic RA). Worthy of notice are differences to the previously quoted Chinese study: genera which were more abundant in this group of patients, in the Chinese study were less frequently observed in RA than in healthy persons [23]. These examples demonstrate the complexity of intestine ecosystems. The previously mentioned genus Prevotella is worthy of greater emphasis in the conclusions. These bacteria found in RA patients (not yet subjected to treatment with DMARDs) and in patients with inflammatory bowel disease may induce enteritis in mouse models. It is also suspected that Prevotella is one of organisms which metabolize L-carnitine (originating from red meat) to trimethylamine $\mathrm{N}$-oxide (TMAO), and elevated level of this substance constitutes risk factor for accelerated atherosclerosis. The mechanism may contribute to elevated cardiovascular risk in patients with RA. Prevotella possesses epitopes common with HLA DRB1, yet what is surprising, Prevotella with such epitopes was less numerous in patients with early RA than in the control group (which may be linked to the mutual influence of the immune system on the microbiome and may indicate that the disease must be triggered by other factors). The purine synthesis pathway is less active in Prevotella than in Bacteroides, which may influence the efficiency of oral methotrexate. Tetrahydrofolate reductase in Bacteroides may bind methotrexate in the intestine, thus reducing its efficiency and patients with the dominance of Prevotella may respond better to oral administration of methotrexate. However, this influence requires further evaluation [23].

Different results regarding Prevotella copri were obtained in the Mayo Clinic on the basis of stool evaluations from 40 patients with RA and control group of 32 persons (relatives and unrelated persons). No relationship between the occurrence of Prevotella copri with early RA was determined, yet such relationship was found for Eggerthella, Faecalibacterium, and Collinsella. In the subsequent part of the study administration of Collinsella to mice intensified susceptibility to collagen-induced arthritis. In vitro Collinsella aerofaciens causes reduction in the expression of tight junction proteins and induces IL-17 expression [24]. Researchers considered the causes for different composition of microbiome in healthy and sick persons. It is likely that 
patients with RA suffer from deficiency of the taxa necessary for physiological reactions of the immune system and for relieving of its excessive agitation. According to another hypothesis, the RA "susceptibility" genes, especially MHC genes, favor maintaining of certain species or strains of bacteria, which in turn influence the development of arthritis or maintaining its chronic state [3]. In addition, the hypothesis of the toxemia factor has been raised. According to this hypothesis, excess of Gram-negative bacteria in the lumen of intestine results in the increase of toxic metabolites, which penetrate the blood vessels and promote arthritis [19]. On the other hand, deficiency of certain bacteria species (e.g., Bacteroides thetaiotaomicron) may lead to permeability of the intestinal barrier [3].

Therapeutic agents in RA, which influence the intestinal flora and the joint-gut axis have been used since 1940s. Some of these agents are used as disease-modifying drugs. Such double action (antibacterial and immunosuppressive) is exhibited by sulfasalazine and minocycline (tetracycline used as disease-modifying drug in the USA) [19].

\section{Oral cavity}

Oral cavity contains approximately $10^{10}$ of bacteria belonging to approx. 700 species, of which number about $34 \%$ is not subjected to in vitro culture, and $17 \%$ of the remaining number have not been scientifically described. Microorganisms colonize the mucosa of the entire oral cavity, however special attention must be paid to the periodontium. The microbiome of the oral cavity in patients with periodontium diseases differs from persons without the disease (Table III).

Numerous works indicate increased frequency and severity of periodontium diseases in patients with RA.

Table III. Bacteria dominating in healthy oral cavity and in periodontal disease $[19,50]$

\begin{tabular}{|ll|}
\hline Healthy oral cavity & Periodontal disease \\
\hline Firmicutes & Porphyromonas gingivalis \\
Bacteroidetes & Treponema denticola \\
- clone BU063 & Tannerella forsythia \\
Proteobacteria & Deferribacteres - clone D084 \\
Actinobacteria & and BH017 \\
Spirochaetes & Bacteroidetes - clone AU126 \\
Fusobacteria & Megasphaera-clone BB166, \\
Deferribacteres & OP11 phylum-clone X112 \\
- clone W090 & TM7 phylum - clone I025 \\
Atopobium rimae & Eubacterium saphenum \\
Atopobium parvulum & Porphyromonas endodontalis \\
& Prevotella denticola \\
& Cryptobacterium curtum \\
\hline
\end{tabular}

American researchers analyzed group of 4461 participants, including 103 with RA. In patients with RA, lower level of caries was found, but higher number of missing teeth (OR 2.27) and more frequent periodontosis (OR 1.82 ); the combined occurrence of lack of teeth or periodontosis with RA was particularly strongly marked in seropositive patients (OR 4.5) [25].

A team from Taiwan demonstrated relationship between presence of periodontitis in interview and the risk of the disease (OR 1.16) conducted in a large epidemiological study based on the register of close to 14,000 patients with newly diagnosed RA [26].

However, does the coexistence mean a causal relationship? Does periodontitis lead to RA? Periodontal diseases and RA are bound by combined mechanisms of inflammation and tissue damage. Cytokines IL-1, IL-6, metalloproteinases and active oxygen species are expressed in both diseases. In addition, smoking cigarettes constitutes a predisposing factor for both diseases. The main pathogen of periodontal disease is Porphyromonas gingivalis. It is capable of citrullination of its own and host's proteins thanks to production of peptidylarginine deiminase and gingipains, enzymes which expose C-terminus residues of arginine, enabling citrullination. Antibodies against citrullinated proteins (such as collagen type II, fibrinogen, fibrin, vimentin, $\alpha$-enolase) play important role in the RA pathomechanism [27]. Periodontal disease is accompanied by intensified bone destruction as the result of enzymes produced by the host due to immune reaction, and the periodontium tissues are found to contain citrullinated proteins. Also the serum of patients with chronic periodontitis was found to contain antibodies to citrullinated proteins (anti-CEP-1) and their non-citrullinated equivalents (fibrinogen, vimentin). It is suspected that the host's protein citrullination mechanism may provoke formation of new antigens and reduce the immune tolerance in predisposed persons. The initial immune response may take place in the oral cavity during $P$. gingivalis infection, then becoming strengthened in the joint synovitis, where human peptidylarginine deiminase may citrullinate endogenous proteins. It has been discovered that there are other organisms (than P. gingivalis) which cause periodontal disease: Anaerglobus geminatus and Prevotella/Leptotrichiaare related to the presence of anti-citrullination antibodies and RA [19].

Periodontal disease treatment may decrease RA activity. In a prospective study conducted in Turkey, patients with RA and periodontitis were subjected to therapy consisting of providing instruction on the oral cavity hygiene, removal of scaling and root planingand removal of caries from tooth crown. After 3 months of treatment decrease in the activity of RA measured with 
DAS-28, decrease of OB value and CRP and TNF concentration were observed. Effects were more clearly marked in patients with high initial activity of the disease [28]. In addition, a Polish study conducted by the Wroclaw Medical University has revealed that dental treatment of periodontal disease may reduce the activity of RA in certain patients [29].

On the other hand, periodontal disease may lead to the lack of anti-TNF treatment response, and such conclusion was drawn based on the observation of $18 \mathrm{pa}$ tients of the Sao Paulo University [30].

Results of the prospective randomized study ESPERA, conducted in France, where patients with RA and the concomitant periodontosis are subjected not only to scaling and root-planing procedures, use of local antiseptics and hygiene instruction, but also systemic antibiotic treatment, are expected. DAS28, ACR 20, ACR 50 and ACR 70 indexes will be evaluated within the study [31].

Meta-analysis conducted by Kaur et al. [32] in 2014 demonstrated that periodontal treatment of RA patients was linked to a significant decrease of $O B$, and tendency to reduce DAS28 and TNF concentration. Five studies were included (each with the number of participants ranging between 29 and 55).

On the other hand, analysis of a cohort of American women, including 292 cases of RA, did not demonstrate an increased risk of RA among persons with periodontal disease in the history [33].

Although Scher et al. [34] determined higher intensity of periodontitis for patients with newly diagnosed RA than in the control group, yet the frequency of Porphyromonas colonization remained unaltered $(78.4 \%$ and $83.3 \%$ respectively). The periodontal microbiome composition was more strongly linked to the intensification of periodontitis than to the presence of RA, yet Prevotella spp. and Leptotrichia spp. occurred solely in persons with RA $(32.2 \%$ and $25.8 \%$ of these patients, respectively) independently of the intensification of the periodontal disease [34].

Zhang et al. [22] sequenced DNA from dental plaque, saliva and stool of RA patients and healthy persons. Saliva of RA patients contained more bacteria of the genus Prevotella, except for P. intermedia, which was more common in the control group. On the other hand, Prevotella spp. was more frequently found in healthy persons. In addition, such species related to periodontal disease as Porphyromonas gingivalis, Tannerella forsythia and Treponema spp. were found in greater numbers in the control group than in the RA group. The study did not determine the clinical state of the oral cavity and periodontium [22].

\section{Respiratory track}

Nowadays, thanks to the molecular identification based on 16S rRNA sequence it turns out that various bacteria species can be found in lower respiratory tracts, and their species composition differs from the flora of the upper respiratory tracts. Research on the lower respiratory tract include low groups of patients due to the increased invasiveness of sample collection method (bronchoalveolar lavage - BAL, bronchial mucosal biopsy, lung transplant examination). However, it turns out that lower respiratory tracts of healthy persons are also inhabited by Actinobacteria, Bacterioidetes, Firmicutes and Fusobacteria. In state of health a wide diversity of the bacterial flora is present which ensures homeostasis. The microbiome of a healthy human differs from the microbiome of person suffering from respiratory diseases [5]. During disease (chronic obturatory pulmonary disease, asthma, interstitial pulmonary fibrosis) the diversity is reduced and disorders in the ratios between individual bacteria species occur. Typically, the number of Proteobacteriaceae increases. In some patients with early RA or RA risk factors (family history, seropositivity) the concentrations of antibodies (anti-CCP, RF class IgM) were higher in the sputum than in the serum or were even found solely in sputum with the absence of antibodies in the serum. It has been suggested that the bacteria originating from the periodontium penetrating to lower respiratory tracts through citrullination contribute to the development of the auto-immune process within the lungs, thus they can constitute site of antibody production during early RA [19, 35]. Scher et al. [36] performed a study determining the direct composition of the lung microbiome on the RA incidence. They investigated the BAL of 20 untreated early RA patients, pulmonary sarcoidosis patients an healthy controls. The high degree of similarity between thelung microbiome in RA and sarcoidosis was revealed. Interestingly, despite previous speculations, the authors report a general underrepresentation of Actinomyces, Prevotella and Porphyromonas as well in the BAL of RA patients. An association with erosive disease was observed with the presence and abundance of Pseudonocardia in the RA [36].

\section{Urinary system}

Under normal conditions urine in the bladder, ureters, renal pelvis and calyxes is sterile. Microorganisms, typically without influence on the infection of urinary tract, may occur in the distal part of the urethra. These are typically staphylococci, lactic acid bacilli, non-haemolytic streptococci, saprophytic Corynebacteria. 
Typical etiology of urinary tract infections consists of Gram-negative intestinal bacilli of the family Enterobacteriaceae: Escherichia coli, and less frequently: Proteus spp. Klebsiella spp., Providencia spp., Enterobacter spp. Pseudomonas aeruginosa and Acinetobacter spp. Among Gram-positive bacteria, infections are caused mainly by Enterococcus, Staphylococcus (particularly S. saprophyticus), Streptococcus spp. (particularly S. agalactiae) and Corynebacterium urealyticum [37].

Among the above genera of special interest in relation to rheumatoid arthritis is the genus Proteus. Already in the 1980s an elevated presence of antibodies against Proteus mirabilis was found in patients with RA compared to AS patients and healthy persons [38]. Subsequently, it was demonstrated that Proteus antigens exhibit cross-reaction with anti-HLA DR4 antibodies.

The following course of events has been suggested: Proteus infection of urinary tract causes production of antibodies against the bacteria, some of the antibodies possess anti-HLA DR4 activity. Cells with HLA DR 4 expression bind antibodies, cytokines are produced, complement is activated and the local response in the joints develops (Proteus-reactive arthritis). Repeated inflammation leads to rheumatoid arthritis [39].

In 1997, Wilson et al. [40] examined a group of 89 patients with RA and isolated Proteus mirabilis in the urine of $63 \%$ of women and $50 \%$ of men, whereas in the control group of healthy persons in $32 \%$ of women and $11 \%$ men, respectively. Antibodies against $P$. mirabilis were found in greater number in serum samples from patients with RA than in the group without RA. The relationship was not found for Escherichia coli. Antibody concentrations correlated with higher count of Proteus bacteria in urine samples. These results support the hypothesis on Proteus infection constituting RA etiological factor [40].

In 1999, Senior et al. [41] demonstrated significantly more frequent Proteus mirabilis infections of the urinary tract in RA [analyzed was urine of 76 patients with RA and 48 of control group]. Urinary tract infection was found in only $4 \%$ of healthy persons and in 33\% patients with RA, and Proteus mirabilis infection was dominant in the latter group (two-fold more frequent than E. coli). Proteus mirabilis was cultured in $52 \%$ of samples from patients with RA and urinary tract infection, however the increase was typically slight $\left(<10^{4} \mathrm{CFU} / \mathrm{ml}\right)$. Patients with RA also exhibited presence of IgM, IgA and IgG antibodies to $P$. mirabilis in the serum and in the urine. The study result indicates that patients with RA have asymptomatic $P$. mirabilis infections more frequently or with longer course than other patients, which may constitute the trigger factor for RA [41].
Arabski et al. [42] demonstrated significantly more frequent presence of antibodies to lipopolysaccharide (LPS) of $P$. mirabilis in patients with RA and at the same time it was not found to be related to polymorphism of the TLR4 gene. The TLR4 receptor is responsible for the lipopolysaccharide recognition. The special structure of LPS in Proteus protects the bacteria against bactericidal properties of the serum. Particular resistance to the effect of complement was exhibited by LPS with the serotype $\mathrm{O} 49$ which reacted with the serum of $74 \%$ RA patients. Chronic infection triggers activation of non-specific immune mechanisms, which may contribute to the development of RA. Some authors have proposed to subject patients with early RA to eradication of Proteus urinary tract infection at an early stage in order to prevent disease progression [43, 44]. However, further research is necessary to determine efficacy of such intervention.

\section{Conclusion}

The causal relationships between microbiome disorders and the immune reaction contributing to the development of rheumatoid arthritis have not been entirely explained: is it the state of the immune system of the host with rheumatoid arthritis that causes such composition of his microbiome? Is altered microbiome composition the cause, or the result of inflammation? The most abundant group of intestinal microorganisms does not allow form specifying any bacteria species which would favor the development of rheumatoid arthritis, and we are dealing here with complex mutual interactions between intestinal microorganisms and the immune system of the entire host's organism. The role of inflammation focuses (of dental origin, urogenital tract) in rheumatoid arthritis has already been suggested in 1920s [45]. New observations on the microbiome of periodontal inflammations and asymptomatic urinary tract infections demonstrate that those hypotheses had not been entirely invalid. Although rheumatoid arthritis doubtlessly is not an infectious disease, the role of the immune system response to microorganisms in the etiology of the disease is still worthy of further research, particularly conducted on larger populations.

The authors declare no conflict of interest.

\section{References}

1. Kucharz EJ. Reumatoidalne zapalenie stawów. In: Wielka interna. Reumatologia. Puszczewicz M (ed.). Medical Tribune Polska, Warszawa 2010; 75-78.

2. Tlaskalová-Hogenová H, Stepánková R, Hudcovic T, et al. Commensal bacteria (normal microflora), mucosal immunity and 
chronic inflammatory and autoimmune diseases. Immuno Lett 2004; 93: 97-108.

3. Vaahtovuo J, Munukka E, Korkeamäki M, et al. Fecal microbiota in early rheumatoid arthritis. J Rheumatol 2008; 35: 15001505.

4. Qin J, Li R, Raes J, et al. A human gut microbial gene catalog established by metagenomic sequencing. Nature 2010; 464: 59-65.

5. Górecka D, Nowiński A, Augustynowicz-Kopeć E. [Microbiome of the lung.] Mikrobiom układu oddechowego. Pneumonol Alergol Pol 2014; 82: 481-485.

6. Keeney KM, Yurist-Doutsch S, Arrieta MC, et al. Effects of antibiotics on human microbiota and subsequent disease. Annu Rev Microbiol 2014; 68: 217-2 35.

7. Eckburg PB, Bik EM, Bernstein CN, et al. Diversity of the human intestinal microbial flora. Science 2005; 308: 1635-1638.

8. Arumugam M, Raes J, Pelletier E, et al. Enterotypes of the human gut microbiome. Nature 2011; 473: 174-180.

9. Macpherson AJ, Harris NL. Interactions between commensal intestinal bacteria and the immune system. Nat Rev Immunol 2004; 4: 478-485.

10. Mazmanian SK, Liu CH, Tzianabos AO, et al. An immunomodulatory molecule of symbiotic bacteria directs maturation of the host immune system. Cell 2005; 122: 107-118.

11. Tukaj S, Lipińska B. Białka szoku termicznego w reumatoidalnym zapaleniu stawów: przyjaciel czy wróg? Postepy Hig Med Dosw (Online) 2011; 65: 427-436.

12. Furusawa Y, Obata Y, Fukuda S, et al. Commensal microbe-derived butyrate induces the differentiation of colonic regulatory T cells. Nature 2013; 504: 446-450.

13. Telesford KM, Yan W, Ochoa-Reparaz J, et al. A commensal symbiotic factor derived from Bacteroides fragilis promotes human CD39(+) Foxp3(+) T cells and Treg function. Gut Microbes 2015; 6: 234-242.

14. Round JL, Lee SM, Li J, et al. The toll-like receptor 2 pathway establishes colonization by a commensal of the human microbiota. Science 2011; 332: 974-977.

15. Rogier R, Koenders MI, Abdollahi-Roodsaz S. Toll-like receptor mediated modulation of $T$ cell response by commensal intestinal microbiota as a trigger for autoimmune arthritis. J Immunol Res 2015; 2015: 527696

16. Ivanov II, Atarashi K, Manel N, et al. Induction of intestinal Th17 cells by segmented filamentous bacteria. Cell 2009; 139 485-498.

17. Atarashi K, Tanoue T, Shima T, et al. Induction of colonic regulatory T cells by indigenous Clostridium species. Science 2011 331: 337-341.

18. Breban MA, Moreau MC, Fournier C, et al. Influence of the bacterial flora on collagen-induced arthritis in susceptible and resistant strains of rats. Clin Exp Rheumatol 1993; 11: 61-64.

19. Brusca SB, Abramson SB, Scher JU. Microbiome and mucosal inflammation as extra-articular triggers for rheumatoid arthritis and autoimmunity. Curr Opin Rheumatol 2014; 26: 10101 10107.

20. Björk J, Kleinau S, Midtvedt T, et al. Role of the bowel flora for development of immunity to hsp 65 and arthritis in three experimental models. Scand J Immunol 1994; 40: 648-652.
21. Liu X, Zou Q, Zeng B, et al. Analysis of fecal lactobacillus community structure in patients with early rheumatoid arthritis. Curr Microbiol. 2013; 67: 170-176.

22. Zhang $X$, Zhang D, Jia $H$. The oral and gut microbiomes are perturbed in rheumatoid arthritis and partly normalized after treatment. Nat Med 2015; 2: 895-905.

23. Scher JU, Sczesnak A, Longman RS, et al. Expansion of intestinal Prevotella copri correlates with enhanced susceptibility to arthritis. Elife 2013; 2: e01202.

24. Chen J, Wright K, Davis JM, et al. An expansion of rare lineage intestinal microbes characterizes rheumatoid arthritis. Genome Med 2016; 8: 43.

25. De Pablo P, Dietrich T, McAlindon TE. Association of periodontal disease and tooth loss with rheumatoid arthritis in the US population. J Rheumatol 2008; 35: 70-76.

26. Chen HH, Huang N, Chen YM, et al. Association between a history of periodontitis and the risk of rheumatoid arthritis: a nationwide, population-based, case-control study. Ann Rheum Dis 2013; 72: 1206-1211.

27. Białowąs K, Swierkot J, Radwan-Oczko M. Rola Porphyromonas gingivalis $\mathrm{w}$ reumatoidalnym zapaleniu stawów i spondyloartropatiach zapalnych. Postepy Hig Med Dosw 2014; 68: 1171 1179.

28. Erciyas K, Sezer U, Ustün K, et al. Effects of periodontal therapy on disease activity and systemic inflammation in rheumatoid arthritis patients. Oral Dis 2013; 19: 394-400.

29. Białowąs K, Mendak-Ziółko M, Duś I, et al. Ocena częstości występowania zakażenia Porphyromonas gingivalis i wpływu leczenia periodontologicznego na aktywność choroby u pacjentów z reumatoidalnym zapaleniem stawów i spondyloartropatiami. Reumatologia 2016; 54 (Supl. 2): 57.

30. Savioli C, Ribeiro AC, Fabri GM, et al. Persistent periodontal disease hampers anti-tumor necrosis factor treatment response in rheumatoid arthritis. J Clin Rheumatol 2012; 18 : 180-184

31. Monsarrat P, Vergnes JN, Cantagrel A, et al. Effect of periodontal treatment on the clinical parameters of patients with rheumatoid arthritis: study protocol of the randomized, controlled ESPERA trial. Trials 2013; 14: 253.

32. Kaur S, Bright R, Proudman SM, et al. Does periodontal treatment influence clinical and biochemical measures for rheumatoid arthritis? A systematic review and meta-analysis. Semin Arthritis Rheum 2014; 44: 113-122.

33. Arkema EV, Karlson EW, Costenbader KH. A prospective study of periodontal disease and risk of rheumatoid arthritis. J Rheumatol 2010; 37: 1801800-4.

34. Scher JU, Ubeda C, Equinda M, et al. Periodontal disease and the oral microbiota in new-onset rheumatoid arthritis. Arthritis Rheum 2012; 64: 3083-3094.

35. Willis VC, Demoruelle MK, Derber LA, et al. Sputum autoantibodies in patients with established rheumatoid arthritis and subjects at risk of future clinically apparent disease. Arthritis Rheum 2013; 65: 2545-2554.

36. Scher JU, Joshua V, Artacho A, et al. The lung microbiota in early rheumatoid arthritis and autoimmunity. Microbiome 2016; 4: 60 . 
37. Holecki M, Duława J, Hryniewicz W, et al. Rekomendacje diagnostyki, terapii i profilaktyki zakażeń układu moczowego u dorosłych. Narodowy Instytut Leków, Warszawa 2015; 7-18.

38. Ebringer A, Ptaszynska T, Corbett M, et al. Antibodies to proteus in rheumatoid arthritis. Lancet 1985; 2: 305-307.

39. Ebringer A, Khalafpour S, Wilson C. Rheumatoid arthritis and Proteus: a possible aetiological association. Rheumatol Int 1989; 9: 223-228.

40. Wilson C, Thakore A, Isenberg D, et al. Correlation between anti-Proteus antibodies and isolation rates of $\mathrm{P}$. mirabilis in rheumatoid arthritis. Rheumatol Int 1997; 16: 187-189.

41. Senior BW, Anderson GA, Morley KD, et al. Evidence that patients with rheumatoid arthritis have asymptomatic 'non-significant' Proteus mirabilis bacteriuria more frequently than healthy controls. J Infect 1999; 38: 99-106.

42. Arabski M, Fudala R, Koza A, et al. The presence of anti-LPS antibodies and human serum activity against Proteus mirabilis S/R forms in correlation with TLR4 (Thr399lle) gene polymorphism in rheumatoid arthritis. Clin Biochem 2012; 45: 1374-1382.
43. Rashid T, Ebringer A. Rheumatoid arthritis is linked to Proteus - the evidence. Clin Rheumatol 2007; 26: 1036-1043.

44. Ebringer A, Rashid T. Rheumatoid arthritis is caused by a Proteus urinary tract infection. APMIS 2014; 122: 363-368.

45. Moreno J. Prevotella copri and the microbial pathogenesis of rheumatoid arthritis. Reumatol Clin 2015; 11: 61-63.

46. Human Microbiome Project Consortium. Structure, function and diversity of the healthy human microbiome. Nature 2012; 486: 207-214.

47. Yatsunenko T, Rey FE, Manary MJ, et al. Human gut microbiome viewed across age and geography. Nature 2012; 486: 222-227.

48. McDonald D, Birmingham A, Knight R. Context and the human microbiome. Microbiome 2015; 3: 52.

49. Forbes JD, Van Domselaar G, Bernstein CN. The Gut Microbiota in Immune-Mediated Inflammatory Diseases. Front Microbiol 2016; 7: 1081.

50. Kumar PS, Griffen AL, Barton JA, et al. New bacterial species associated with chronic periodontitis. J Dent Res 2003; 82: 338-344. 